\title{
Differences between Indonesia and Singapore based on PISA 2015: Five-factor students' perception in science education
}

\author{
Janu Arlinwibowo ${ }^{1}$, , Hanif Cahyo Adi Kistoro ${ }^{2}$, Heri Retnawati ${ }^{3}$, Gulzhaina Kuralbayevna \\ Kassymova ${ }^{4}$, Bagdaulet Kenzhalyevich Kenzhaliyev ${ }^{4}$ \\ ${ }^{1}$ Universitas Muhammadiyah Kudus. Jalan Ganesha I Purwosari Kudus 59316, Jawa Tengah, Indonesia \\ ${ }^{2}$ Universitas Ahmad Dahlan. Jalan Kapas 9, Semaki, Umbulharjo, Yogyakarta 55166, Indonesia \\ ${ }^{3}$ Universitas Negeri Yogyakarta. Jalan Colombo No. 1, Yogyakarta 55281, Indonesia \\ ${ }^{4}$ Satbayev University. 22a Satpaev str. 050013, Almaty, The Republic of Kazakhstan \\ * Corresponding Author. Email: janu@umkudus.ac.id
}

Received: 22 June 2020; Revised: 1 July 2020; Accepted: 8 July 2020

\begin{abstract}
As a neighbouring country whose location is very close, there is a unique fact where the results of the PISA study show very different results between Indonesia and Singapore. Students' perceptions of learning have an important role to detect the quality of learning. Thus, this study aims to determine the factors of student perception of natural science learning and the differences between the two countries based on these factors. The sample in this study were 5870 Indonesian students and 5272 Singaporean stu-dents who took the 2015 PISA survey. The research data were the results of the PISA survey (codes ST098, ST100, ST103, and ST104) regarding student perception of natural science learning. The data analysis technique used is Principal Component Analysis to detect factors and Discriminant Analysis to show diffe-rences between the two countries. Students' perceptions of science learning in Singapore and Indonesia can be classified into five factors: Practicum, Assistant, Explorative, Counseling, and Collaborative. Based on these factors, there are differences in the perception of the implementation of science learning between Indonesian and Singaporean students. Indonesian students tend to be stronger in defining that science learn-ing is full of exploration, collaboration, and teachers play the role of counsellor very well, while Singapore students feel more than practical learning based on science and teachers provide student assistance in dealing with difficulties in the learning process.
\end{abstract}

Keywords: PISA 2015, Students' Perception, Science Education, Different, Indonesia and Singapore.

How to Cite: Arlinwibowo, J., Kistoro, H., Retnawati, H., Kassymova, G., \& Kenzhaliyev, B. (2020). Differences between Indonesia and Singapore based on PISA 2015: Five-factor students' perception in science education. Jurnal Inovasi Pendidikan IPA, 6(1), 79-87. doi:https://doi.org/10.21831/jipi.v6i1.32637

\section{INTRODUCTION}

International surveys of PISA (Program for International Student Assessment), international studies such as TIMSS (Trends in Mathematics and Science Study) and PIRLS (Progress in International Reading Literacy Study) have been conducted by researchers in the world. The purpose of the surveys is to measure students' abilities and skills, especially related to solving everyday problems (Ceylan \& Abac1, 2013). Thus there will be a clear world map related to education which can then be used as a means for self reflexes.

PISA is an international survey that has a mission to evaluate the process and educational achievements in each country (Fenanlampir et al., 2019). Mathematics, literacy, science, and problemsolving are the focus of the 2015 PISA Survey. In addition, the 2015 PISA survey also added an assessment of financial literacy which is an option. The PISA 2015 survey participants were around 540,000 who were representatives of around 29 million children aged 15 years (students) from 72 participating countries (Organisation for Economic Co-Operation and Development, 2015).

Indonesia and Singapore are neighbours. Although the location is very close, there are a lot of differences between the two countries, for example from the size of the country, population, to social aspects. From the aspect of education, both of them can be compared through the results of PISA 2015 because they both are members of the OECD. Differences in the results of international surveys between Indonesia and Singapore are very different (Yang \& Sianturi, 2020). Singapore is the best (the first rank 


\section{Jurnal Inovasi Pendidikan IPA, 6 (1), 2020 - 80}

Janu Arlinwibowo, Hanif Cahyo Adi Kistoro, Heri Retnawati, Gulzhaina Kuralbayevna Kassymova, Bagdaulet Kenzhalyevich Kenzhaliyev

in PISA 2015) with an average score of 556 while Indonesia is ranked 62 with a score of 403 (Organization for Economic Co-operation and Development, 2016a). The difference in PISA results becomes a big question that must be studied by the Indonesian people (Suprapto, 2016)

In PISA 2015, opinions related to learning are asked of teachers and students. The strategy is used so that the data obtained is valid (Lau \& Lam, 2017). One of the results of the service data from PISA is students' perceptions of science learning. This perception of data is interesting because it shows that there is a positive relationship between perception and learning achievement (Ahmed et al., 2018; Mayya \& Roff, 2004). Even Ganeb and Montebon (2018) stated that it gives an influence on students' ability in mastering material. Understanding students' aspirations for learning and working in science continues to be a major concern for science educators (Sheldrake et al., 2017). Students' perceptions of a lesson can be used as an overview of the educational situation and also as a benchmark of quality. Besides, perceptions describe the experiences of students which influence their attitude towards learning (Wang, 2012).

Thus it is interesting to compare the perceptions of students in Indonesia and Singapore towards science lessons. It is important to know whether there are significant differences in students' perceptions of science lessons in Indonesia and Singapore so that policymaking can be done as a basis for developing the learning process and learning environment.

\section{METHOD}

This research is survey research. The survey process was not carried out independently by researchers but researchers took data from the 2015 PISA survey. Survey data were selected and grouped for later data to be taken by the research objectives.

\section{Sample}

Around 540,000 students were involved in the PISA survey in 2015, representing around 29 million children aged 15 years in schools from 72 participating countries. Indonesia and Singapore participated in the PISA survey in 2015. This study involved data on 6513 Indonesian students and 6115 Singaporean students participating in PISA 2015. However, not all students had sufficient data to be analyzed. Thus the election was carried out so that 5870 Indonesian students and 5272 Singapore students were selected.

\section{Instrument}

The instrument used in this study was a student instrument in the form of a questionnaire to assess natural science learning. Taken 23 items related to students' perceptions of science learning in their schools (ST098, ST100, ST103, and ST104). All items have the same format, which is a questionnaire with 4 graded answer choices.

\section{Data Analysis}

Differences will be made between the situation in Indonesia and Singapore. For this reason, the first analysis is to reduce and classify the data with the principal component of the analysis so that through the MSA assessment it can be identified which items are issued and grouped. Then in distinguishing the two groups done by discriminant function analysis (DFA) which is usually used to classify individuals based on one or more actions or to realize group differences (Green et al., 2000) conducted in this study. DFA is done to distinguish low-performing countries (Indonesia) and highperformance countries (Singapore) with respect to students' perceptions of natural science education in the 2015 PISA survey.

\section{RESULTS AND DISCUSSION}

\section{Results}

23 items in the 2015 PISA survey measure students' perceptions related to learning science in the classroom. The results of the survey conducted in Indonesia and Singapore were conducted in 6513 and 6115. However, the selection of complete data was carried out so that what was included in the analysis were 5870 Indonesian students and 5272 Singapore students. The first stage of the analysis is a partial 
Jurnal Inovasi Pendidikan IPA, 6 (1), 2020 - 81

Janu Arlinwibowo, Hanif Cahyo Adi Kistoro, Heri Retnawati, Gulzhaina Kuralbayevna Kassymova, Bagdaulet Kenzhalyevich Kenzhaliyev

component analysis to group 23 items into the main factors. The results of the PCA are as follows (Table $1)$.

Table 1. KMO and Bartlett's Test

\begin{tabular}{lll}
\hline \multicolumn{2}{l}{ Kaiser-Meyer-Olkin Measure of Sampling Adequacy. } & .896 \\
& Approx. Chi-Square & 93460.161 \\
Bartlett's Test of Sphericity & df & 253 \\
& Sig. & 0.000 \\
\hline
\end{tabular}

The results of the KMO analysis and Bartlett's Test (Table 1) show that the Kaiser-Meyer-Olkin Measure of Sampling Adequacy yields a value of 0.896 which is $>0.5$ so that there is sufficient sample in performing PCA. Furthermore, the significance of Bartlett's Test of Sphericity shows a value of 0,000 $<0.05$, so it can be concluded that there is a relationship between factors. Thus, the second prerequisite test has been fulfilled so that further analysis can be done.

Table 2. Eigenvalues

\begin{tabular}{cccc}
\hline \multirow{2}{*}{ Component } & \multicolumn{3}{c}{ Initial Eigenvalues } \\
\cline { 2 - 4 } & Total & \% of Variance & Cumulative \% \\
\hline 1 & 6.477 & 28.161 & 28.161 \\
2 & 2.345 & 10.194 & 38.355 \\
3 & 1.956 & 8.505 & 46.860 \\
4 & 1.616 & 7.026 & 53.886 \\
5 & 1.190 & 5.172 & 59.058 \\
6 & .857 & 3.726 & 62.784 \\
\hline
\end{tabular}

Table 3. Rotated Component Matrix

\begin{tabular}{|c|c|c|c|c|c|}
\hline \multirow{2}{*}{ Item } & \multicolumn{5}{|c|}{ Component } \\
\hline & 1 & 2 & 3 & 4 & 5 \\
\hline Students are allowed to explain their opinions & .444 & & & & \\
\hline Students practice experiments in the laboratory & & & & & .699 \\
\hline Students are expected to state the reasons for the question about science & .735 & & & & \\
\hline $\begin{array}{l}\text { Students are asked to make conclusions from the experiments they have } \\
\text { done }\end{array}$ & .517 & & & & \\
\hline $\begin{array}{l}\text { The teacher explains how an idea in science can be applied to some } \\
\text { different phenomena (for example, the movement of objects, materials } \\
\text { with similar properties) }\end{array}$ & .555 & & & & \\
\hline Students are allowed to plan their experiments & 670 & & & & \\
\hline There is a debate class regarding investigations. & .597 & & & & \\
\hline $\begin{array}{l}\text { The teacher explains well the relationship between science concepts and } \\
\text { our lives }\end{array}$ & .649 & & & & \\
\hline Students are asked to investigate to test the idea & .663 & & & & \\
\hline The teacher is interested in each student's learning activities & & & .596 & & \\
\hline The teacher provides additional assistance for students who need it & & & .744 & & \\
\hline The teacher helps students in learning & & & .785 & & \\
\hline The teacher continues to teach until students understand & & & .722 & & \\
\hline The teacher allows students to express their opinions & & & .663 & & \\
\hline The teacher explains scientific ideas & & & & .716 & \\
\hline There was a discussion of all students in the class with the teacher. & & & & .703 & \\
\hline The teacher discusses our questions & & & & .790 & \\
\hline The teacher demonstrates an idea & & & & .763 & \\
\hline The teacher told me about my achievements in science lessons & & 690 & & & \\
\hline My teacher gave me input about my strengths in science subjects & & .763 & & & \\
\hline The teacher told me what material I could still improve & & .813 & & & \\
\hline The teacher told me how to improve my performance & & .807 & & & \\
\hline The teacher advised me how to achieve my learning goals & & .758 & & & \\
\hline
\end{tabular}


Jurnal Inovasi Pendidikan IPA, 6 (1), 2020 - 82

Janu Arlinwibowo, Hanif Cahyo Adi Kistoro, Heri Retnawati, Gulzhaina Kuralbayevna Kassymova, Bagdaulet Kenzhalyevich Kenzhaliyev

Based on the initial eigenvalue (Table 2) shows that 5 components have an eigenvalue of more than 1 , it can be concluded that there are 23 items collected into 5 factors. Table 3 is a grouping of items in each factor.

Grouping is indicated by a loading factor above 0.4 or the highest among others. The data above shows a grouping that can be summarized in Table 4.

Table 4. Grouping and Naming Factors

\begin{tabular}{|c|c|}
\hline Item & Factor \\
\hline $\begin{array}{l}\text { Students are allowed to explain their opinions } \\
\text { Students are expected to state the reasons for the question about science } \\
\text { Students are asked to make conclusions from the experiments they have done } \\
\text { The teacher explains how an idea in science can be applied to some different phenomena (for } \\
\text { example, the movement of objects, materials with similar properties) } \\
\text { Students are allowed to plan their experiments } \\
\text { There is a debate class regarding investigations. } \\
\text { The teacher explains well the relationship between science concepts and our lives } \\
\text { Students are asked to investigate to test the idea }\end{array}$ & Explorative \\
\hline $\begin{array}{l}\text { The teacher told me about my achievements in science lessons } \\
\text { My teacher gave me input about my strengths in science subjects } \\
\text { The teacher told me what material I could still improve } \\
\text { The teacher told me how to improve my performance } \\
\text { The teacher advised me how to achieve my learning goals }\end{array}$ & Counselling \\
\hline $\begin{array}{l}\text { The teacher is interested in each student's learning activities } \\
\text { The teacher provides additional assistance for students who need it } \\
\text { The teacher helps students in learning } \\
\text { The teacher continues to teach until students understand } \\
\text { The teacher allows students to express their opinions }\end{array}$ & Assistant \\
\hline $\begin{array}{l}\text { The teacher explains scientific ideas } \\
\text { There was a discussion of all students in the class with the teacher. } \\
\text { The teacher discusses our questions } \\
\text { The teacher demonstrates an idea }\end{array}$ & Collaborative \\
\hline Students practice experiments in the laboratory & Practicum \\
\hline
\end{tabular}

Table 4 shows that 23 items are divided into 5 major factors, namely exploratory, counselling, assistive, collaborative, and practicum. Explorative is a teacher activity that aims to explore and develop students' abilities. Counselling is the teacher's role in providing various suggestions regarding problemsolving strategies and techniques to students. Assistive is the teacher's role in assisting students technically against student learning difficulties. The collaborative is the ability of the teacher to manage the class so that the nuances of learning become two-way. Whereas practicum is the implementation of practicum in laboratories.

General characteristics of items loaded on the same factor are considered and these eight factors are named accordingly. Table 5 shows the name of the factor, eigenvalue, and total variance.

Table 5. Factor Name, Abbreviation, Eigenvalues, and \% Variance

\begin{tabular}{lccc}
\hline \multicolumn{1}{c}{ Factor Name } & Abbreviation & Eigenvalues & \% Variance \\
\hline Exploratory & F1 & 6.477 & 28.161 \\
Counselling & F2 & 2.345 & 10.194 \\
Assistive & F3 & 1.956 & 8.505 \\
Collaborative & F4 & 1.616 & 7.026 \\
Practicum & F5 & 1.190 & 5.172 \\
\hline
\end{tabular}

The next step is discriminant analysis (DFA) using average data from each factor. DFA is run based on factor scores extracted from factor analysis. The DFA dependent variable is the countries that are Indonesia and Singapore. The independent variables, on the other hand, are named based on factor analysis, namely exploratory, counselling, assistive, collaborative, and practicum. DFA analysis begins by analyzing the covariance matrix data presented in Table 6 .

According to Table 6, the M Box test is significant, because the p-value is less than the $5 \%$ significance level $(p$-value $=0.00<0.05)$, therefore the results of the analysis reject the homogeneous matrix hypothesis at the $95 \%$ confidence interval. However, the absolute value of the Log Determi-nants does 
Jurnal Inovasi Pendidikan IPA, 6 (1), 2020 - 83

Janu Arlinwibowo, Hanif Cahyo Adi Kistoro, Heri Retnawati, Gulzhaina Kuralbayevna Kassymova, Bagdaulet Kenzhalyevich Kenzhaliyev

not differ significantly and the sample size for each level of the dependent group is more than five times the number of independent variables.

Table 6. Covariance matrix

\begin{tabular}{ccc}
\hline & & Test Results \\
\hline & Box's M & 667.936 \\
F & Approx. & 44.508 \\
& df1 & 15 \\
& df2 & 487577423.996 \\
\hline
\end{tabular}

\begin{tabular}{ccc}
\hline & Log Determinants & \\
\hline Classification & Rank & Log Determinant \\
\hline .00 & 5 & -5.395 \\
1.00 & 5 & -4.954 \\
Pooled within-groups & 5 & -5.126 \\
\hline
\end{tabular}

Eigenvalues and canonical correlations from the second discriminant analysis were found 0.34 and 0.504, respectively. Based on the results in Table 7, Eigenvalue is $0.341^{\mathbf{a}}$ and Canonical Correlation is 0.504 in the sense that $50.4 \%$ of the Discriminant model can be explained by explorative, counselling, assistive, collaborative, and practicum variables, the remaining $49.6 \%$ is explained by other variables. The significance value is 0.000 , indicating that there is a significant difference between the response patterns of Indonesian and Singaporean students to the composite variable at a significance level of 0.05 . Table 7 is a summary of the various data above.

Table 7. Summary of tests of significance and statistical relationships for DFA

\begin{tabular}{cccccccc}
\hline Function & Eigenvalue & $\%$ of Variance & Canonical Correlation & Wilks' Lambda & Chi-square & df & Sig. \\
\hline 1 & $.341^{\mathrm{a}}$ & 100.0 & .504 & .746 & 3266.854 & 5 & 0.000 \\
\hline
\end{tabular}

All factors have been shown to have a significant effect. This is indicated by all the significance of each variable $0,000<0.05$ so that it shows that $\mathrm{H}_{0}$ : the variable does not affect is rejected. So empirically all factors have a significant influence on the differences between the two groups. A summary of the significance tests for each variable is summarized in Table 8.

Table 8. Variables Entered/Removed ${ }^{\text {a, b, c, d }}$

\begin{tabular}{cccccccc}
\hline \multirow{2}{*}{ Step } & \multirow{2}{*}{ Entered } & \multirow{2}{*}{ Stat } & Between & \multicolumn{4}{c}{ Min. D Squared } \\
\cline { 3 - 7 } & & Groups & Stat & df1 & df2 & Sig. \\
\hline 1 & Practicum (F5) & .257 & IND \& SGP & 713.984 & 1 & 11140.000 & 0.000 \\
2 & Explorative (F1) & .797 & IND \& SGP & 1107.037 & 2 & 11139.000 & 0.000 \\
3 & Collaborative (F4) & 1.281 & IND \& SGP & 1185.618 & 3 & 11138.000 & 0.000 \\
4 & Assistive (F3) & 1.364 & IND \& SGP & 946.783 & 4 & 11137.000 & 0.000 \\
5 & Counseling (F2) & 1.367 & IND \& SGP & 759.190 & 5 & 11136.000 & 0.000 \\
\hline
\end{tabular}

The discriminant function (DF) which shows which structure of factors is significantly different in distinguishing the two groups of countries is listed in Table 9.

Table 9. Standardized Canonical Discriminant Function Coefficients

\begin{tabular}{lr}
\hline & \multicolumn{1}{c}{ Function } \\
\hline Practicum (F5) & 1 \\
Explorative (F1) & 1.048 \\
Collaborative (F4) & -.768 \\
Assistive (F3) & -.298 \\
Counseling (F2) & .581 \\
\hline
\end{tabular}

Table 9 produces a discriminant function as follows:

$\mathrm{DF}=1.048 \mathrm{~F} 5-0,768 \mathrm{~F} 1-0,298 \mathrm{~F} 4+0,581 \mathrm{~F} 3-0,056 \mathrm{~F} 2$

The discriminant function for each group is also partially analyzed to produce an equation to predict the value of each group. Table 10 summarizes the discriminant functions of each group partially. 
Jurnal Inovasi Pendidikan IPA, 6 (1), 2020 - 84

Janu Arlinwibowo, Hanif Cahyo Adi Kistoro, Heri Retnawati, Gulzhaina Kuralbayevna Kassymova, Bagdaulet Kenzhalyevich Kenzhaliyev

Table 10. Classification Function Coefficients

\begin{tabular}{lrr}
\hline & \multicolumn{2}{c}{ Classification } \\
\cline { 2 - 3 } & IND & SGP \\
\hline Practicum (F5) & 8.607 & 6.485 \\
Explorative (F1) & 1.472 & 2.740 \\
Collaborative (F4) & 10.788 & 11.338 \\
Assistive (F3) & 8.964 & 7.975 \\
Counseling (F2) & 8.024 & 8.118 \\
(Constant) & -51.931 & -49.056 \\
\hline
\end{tabular}

Fisher's linear discriminant functions

Based on the analysis results summarized in table 10, the following is the DFA equation for each group:

IND: $-51,931+8.607 \mathrm{~F} 5+1.472 \mathrm{~F} 1+10.788 \mathrm{~F} 4+8.964 \mathrm{~F} 3+8.024 \mathrm{~F} 2$

SGP: $-49.056+6.485 \mathrm{~F} 5+2.740 \mathrm{~F} 1+11.338 \mathrm{~F} 4+7.975 \mathrm{~F} 3+8.118 \mathrm{~F} 2$

The centroid group (Table 11) shows the relative position of the two countries according to DF. This centroid shows, in its function, that the independent variable which is positive is for Indonesia and the negative one is for Singapore. Also, group centroids show average discriminant scores for students' perceptions of natural science learning in Indonesia and Singapore (George \& Mallery, 2006). The results of the Functions at Group Centroids analysis are summarized in Table 11.

Table 11. Functions at Group Centroids

\begin{tabular}{lrr}
\hline \multirow{2}{*}{ Classification } & \multicolumn{2}{c}{ Function } \\
\cline { 2 - 3 } IND (low-perform) & 1 & .553 \\
SGP (high-perform) & & -.616 \\
\hline
\end{tabular}

The factor structure of Singapore students who have high perception scores lies in the factors:

1. Practicum (F5)

2. Assistive (F3)

On the other hand, the composite variable of Indonesian students has a high score on factors:

1. Explorative (F1)

2. Counselling (F2)

3. Collaborative (F4)

The data above appears in the mean score presented in Table 12 .

Table 11. Mean scores of factor structures

\begin{tabular}{cccccc}
\hline \multirow{2}{*}{ Country } & \multicolumn{5}{c}{ Factor } \\
\cline { 2 - 6 } & Explorative & Practicum & Assistive & Collaborative & Counselling \\
\hline IND & 2.4729 & 1.7901 & 3.1087 & 2.5747 & 2.7343 \\
SGP & 2.2278 & 2.1491 & 3.2314 & 2.2427 & 2.6938 \\
\hline
\end{tabular}

The DFA results reveal that students who have good perceptions of science learning related to exploration-based learning, collaboration, and the ability of teachers to play the role of the counsellor are very likely to come from Indonesia, while students who strongly feel that the science learning process in their country is based on practicum and teachers assist in the process learning is most likely to come from Singapore.

\section{Discussion}

Broadly speaking, there are differences in the curriculum in Indonesia and Singapore (Lisarani et al., 2018; Yang \& Sianturi, 2017). The Singapore Science Curriculum Framework is centred on the spirit of scientific inquiry and is based on three domains that are important for scientific practice: knowledge, understanding and application; skills and processes; and ethics and attitudes (Ministry of Education, 2013b, 2013a). The curriculum aims to help students appreciate the pursuit of science and appreciate the important role it plays in everyday life and society. According to the research results of Lisarani et al. (2018) learning in Singapore reflected in the textbook tends to emphasize tasks with verbal representations and closed assignments are the most common types, while application and non- 


\section{Jurnal Inovasi Pendidikan IPA, 6 (1), 2020 - 85}

Janu Arlinwibowo, Hanif Cahyo Adi Kistoro, Heri Retnawati, Gulzhaina Kuralbayevna Kassymova, Bagdaulet Kenzhalyevich Kenzhaliyev

application tasks are divided exactly into two. Whereas in Indonesia, tasks with a combination of representations, non-application tasks, and open-middle tasks are the types that most often appear. While research from Yang and Sianturi (2017) shows that education in Singapore requires higher cognitive abilities than Indonesia.

Science is a concept for understanding natural phenomena (U.S. Department of Education, 2018). At the upper secondary level, students begin to specialize in science subjects such as biology, chemistry, and physics, or combination (Organization for Economic Co-operation and Development, 2016a). Science learning requires teachers who can encourage and model scientific inquiry skills, as well as curiosity, openness to new ideas (Kelley \& Knowles, 2016), and discovery-based (Retnawati et al., 2018). Various enrichment programs complement the formal curriculum at school and national. Science exhibitions, competitions, learning pathways, camps, workshops, and attachments to research institutions function to engage and inspire students at all levels of learning (Organization for Economic Co-operation and Development, 2016a).

The purpose of education in Indonesia is to encourage students to develop their scientific potential (Elvanisi et al., 2018) with the concept of student-centred learning (Retnawati et al., 2017). To realize this, teachers are needed to master theory and practice (Putri \& Jumadi, 2017). Science education in Indonesia has undergone an extraordinary transformation to create a foundation for prosperity and sustainable development. Between 2012 and 2015 alone, science performance among 15-year-old students rose 21 score points. This makes Indonesia the fifth-fastest increasing education system among the 72 who took part in this comparison. Education in Indonesia, including science, is starting to be directed towards materials that are closely related to real phenomena. PISA 2015 also asks students about their beliefs about the nature of scientific knowledge and methods of inquiry (Organization for Economic Co-operation and Development, 2016b).

Based on the above reference support, it can be concluded that the two countries have the same relative view, that is, basing learning on the philosophy of constructivism which is always associated with context-based learning and student-centred. Active learning is put forward so that there is an active relationship between the teacher and students, the teacher with the environment, and students with the environment. Thus, it is not uncommon if students' perception questionnaire on learning science is grouped into Practicum, Assistant, Explorative, Counseling, and Collaborative.

Students' perceptions of science learning can be used as indicators related to the real situation (Bernardo et al., 2008). According to the DFA analysis, there is an indication that Indonesian students are higher in terms of exploratory, counselling, and collaborative, while Singaporean students feel the learning of science in their schools is close to practicum and teachers show assistive nature. Thus, although there are similarities related to the foundation of the implementation of science education, namely student-centred and contextual, in practice there are inequalities so that differences in student perceptions are found.

Based on the 2015 PISA ranking where Singapore has a very high ranking while Indonesia is low, then the portrait of students' perceptions of science learning cannot yet describe a causal phenomenon in a straightforward manner. However, based on the reference it can be identified the relationship of student perception with the results of the 2015 PISA survey. Practicum is a learning strategy that can have a positive impact on learning outcomes (Solikhin et al., 2019). Specifically, practicum can have an influence on students' science process skills (Duda et al., 2019; Kurniawan et al., 2019), increase motivation, curiosity, and self-confidence (Arlianty et al., 2017). Facts show that cognitive demands in Singapore are higher (Yang \& Sianturi, 2017). The high standard of positive achievement coupled with the strong elements of practicum in learning is a factor that might make Singaporean students successful, especially in the PISA survey.

However, the complexity of cases in education makes the conclusion process more complicated (Jacobson et al., 2019). Each country has its educational characteristics (Istiningsih, 2016). The standard of perception of Indonesian and Singaporean students may be different because of various aspects such as the variance of students' cognition. Therefore, it is necessary to conduct a deeper search related to related aspects to complete an objective view to conclude why there are different perceptions between Indonesia and Singapore and their effects on the quality of education. 
Jurnal Inovasi Pendidikan IPA, 6 (1), 2020 - 86

Janu Arlinwibowo, Hanif Cahyo Adi Kistoro, Heri Retnawati, Gulzhaina Kuralbayevna Kassymova, Bagdaulet Kenzhalyevich Kenzhaliyev

\section{CONCLUSION}

Students' perceptions of science learning in Singapore and Indonesia can be classified into five factors, namely Practicum, Assistant, Explorative, Counseling, and Collaborative. Based on these factors, there are differences in the perception of the organization of science learning between Indonesian and Singaporean students. Indonesian students tend to be stronger in defining that science learning is full of exploration, collaboration, and teachers play the role of counsellor very well, while Singapore students feel more than practical learning based on science and teachers provide student assistance in dealing with difficulties in the learning process.

\section{REFERENCES}

Ahmed, Y., Taha, M. H., Al-Neel, S., \& Gaffar, A. M. (2018). Students' perception of the learning environment and its relation to their study year and performance in Sudan. International Journal of Medical Education, 9, 145-150. https://doi.org/10.5116/ijme.5af0.1fee

Arlianty, W. N., Febriana, B. W., \& Diniaty, A. (2017). An analysis of learning process based on scientific approach in physical chemsitry experiment. AIP Conference Proceedings, 1823(March), 020084. https://doi.org/10.1063/1.4978157

Bernardo, A. B. I., Limjap, A. A., Prudente, M. S., \& Roleda, L. S. (2008). Students ' perceptions of science classes in the Philippines. Asia Pacific Education Review, 9(3), 285-295. https://doi.org/10.1007/BF03026717

Ceylan, E., \& Abac1, S. (2013). Differences between Turkey and Finland based on eight latent variables in PISA 2006. International Online Journal of Educational Sciences, 5(1), 10-21. http://www.iojes.net/userfiles/Article/IOJES_1078.pdf

Duda, H. J., Susilo, H., \& Newcombe, P. (2019). Enhancing different ethnicity science process skills: Problem-based learning through practicum and authentic assessment. International Journal of Instruction, 12(1), 1207-1222. https://doi.org/10.29333/iji.2019.12177a

Elvanisi, A., Hidayat, S., \& Fadillah, E. N. (2018). Analisis keterampilan proses sains siswa sekolah menengah atas. Jurnal Inovasi Pendidikan IPA, 4(20), 245-252. https://doi.org/10.21831/jipi.v4i2.21426

Fenanlampir, A., Batlolona, J. R., \& Imelda, I. (2019). The struggle of Indonesian students in the context of TIMSS and PISA has not ended. International Journal of Civil Engineering and Technology, 10(2), 393-406. https://www.iaeme.com/ijciet/IJCIET_Paper.asp?sno=15813

Ganeb, M. D., \& Montebon, D. R. T. (2018). Student perception of science as influenced by Spark Science Learning System (SSLS). Acta Didactica Napocensia, 11(1), 87-99. https://doi.org/10.24193/adn.11.1.7

George, D., \& Mallery, P. (2006). SPSS for windows step by step a simple guide and reference 13.0 update (6th ed.). Allyn \& Bacon.

Green, S. B., Salkind, N. J., \& Akey, T. M. (2000). Using SPSS for Windows; analyzing and understanding data. Pearson.

Istiningsih, I. (2016). Character education of the most developed countries in ASEAN. Journal of Education and E-Learning Research, 3(1), 32-37. https://doi.org/10.20448/journal.509/2016.3.1/509.1.32.37

Jacobson, M. J., Levin, J. A., \& Kapur, M. (2019). Education as a complex system: Conceptual and methodological implications. Educational Researcher, 48(2), 112-119. https://doi.org/10.3102/0013189X19826958

Kelley, T. R., \& Knowles, J. G. (2016). A conceptual framework for integrated STEM education. International Journal of STEM Education, 3(1), 11. https://doi.org/10.1186/s40594-016-0046-z

Kurniawan, W., Darmaji, D., Astalini, A., Kurniawan, D. A., Hidayat, M., Kurniawan, N., \& Nur Farida, L. Z. (2019). Multimedia physics practicum reflective material based on problem solving for science process skills. International Journal of Evaluation and Research in Education (IJERE), 8(4), 590. https://doi.org/10.11591/ijere.v8i4.20258

Lau, K., \& Lam, T. Y. (2017). Instructional practices and science performance of 10 top-performing 


\section{Jurnal Inovasi Pendidikan IPA, 6 (1), 2020 - 87}

Janu Arlinwibowo, Hanif Cahyo Adi Kistoro, Heri Retnawati, Gulzhaina Kuralbayevna Kassymova,

Bagdaulet Kenzhalyevich Kenzhaliyev

regions in PISA 2015. International Journal of Science Education, 39(15), 2128-2149. https://doi.org/10.1080/09500693.2017.1387947

Lisarani, V., Parta, I. N., \& Chandra, T. D. (2018). A comparative analysis of the tasks from the selected mathematics textbooks of Singapore and Indonesia. Jurnal Pendidikan Sains, 6(4), 94-99. https://doi.org/10.17977/jps.v6i4.11802

Mayya, S., \& Roff, S. (2004). Students' perceptions of educational environment: A comparison of academic achievers and under-achievers at Kasturba Medical College, India. Education for Health: Change in Learning \& Practice, 17(3), 280-291. https://doi.org/10.1080/13576280400002445

Ministry of Education. (2013a). Science syllabus. Ministry of Education, Singapore.

Ministry of Education. (2013b). Science syllabus lower secondary: Express course normal (academic) course. Ministry of Education, Singapore.

Organisation for Economic Co-Operation and Development. (2015). Pisa 2015 results in focus.

Organization for Economic Co-operation and Development. (2016a). PISA 2015 top performers. OECD, 1-6. http://ncee.org/wp-content/uploads/2016/12/PISA2015StatvFINAL.pdf

Organization for Economic Co-operation and Development. (2016b). Programme for international student assessment (PISA) results from PISA 2015. OECD, 1-8.

Putri, R. F., \& Jumadi, J. (2017). Kemampuan guru fisika dalam menerapkan model-model pembelajaran pada Kurikulum 2013 serta kendala-kendala yang dihadapi. Jurnal Inovasi Pendidikan IPA, 3(2), 201. https://doi.org/10.21831/jipi.v3i2.8636

Retnawati, H., Arlinwibowo, J., Wulandari, N., \& Pradani, R. (2018). Teachers' difficulties and strategies in physics teaching and learning that applying mathematics. Journal of Baltic Science Education, 17(1), 120-135. http://www.scientiasocialis.lt/jbse/?q=node/643

Retnawati, H., Munadi, S., Arlinwibowo, J., Wulandari, N., \& Sulistyaningsih, E. (2017). Teachers' difficulties in implementing thematic teaching and learning in elementary schools. The New Educational Review, 48(2), 201-212. https://doi.org/10.15804/tner.2017.48.2.16

Sheldrake, R., Mujtaba, T., \& Reiss, M. J. (2017). Science teaching and students' attitudes and aspirations: The importance of conveying the applications and relevance of science. International Journal of Educational Research, 85(August), 167-183. https://doi.org/10.1016/j.ijer.2017.08.002

Solikhin, F., Sugiyarto, K. H., \& Ikhsan, J. (2019). The impact of virtual laboratory integrated into hybrid learning use on students' achievement. Jurnal Ilmiah Peuradeun, 7(1), 81. https://doi.org/10.26811/peuradeun.v7i1.268

Suprapto, N. (2016). What should educational reform in Indonesia look like? - Learning from the PISA science scores of East-Asian countries and Singapore. Asia-Pacific Forum on Science Learning and Teaching, 17(2), 1-22.

U.S. Department of Education. (2018). National board for professional teaching standards certification. In What Works Clearinghouse ${ }^{T M}$.

Wang, M.-T. (2012). Educational and career interests in math: A longitudinal examination of the links between classroom environment, motivational beliefs, and interests. Developmental Psychology, 48(6), 1643-1657. https://doi.org/10.1037/a0027247

Yang, D.-C., \& Sianturi, I. A. (2017). An analysis of Singaporean versus Indonesian textbooks based on trigonometry content. EURASIA Journal of Mathematics, Science and Technology Education, 13(7), 3829-3848. https://doi.org/10.12973/eurasia.2017.00760a

Yang, D.-C., \& Sianturi, I. A. J. (2020). Analysis of algebraic problems intended for elementary graders in Finland, Indonesia, Malaysia, Singapore, and Taiwan. Educational Studies, 00(00), 1-23. https://doi.org/10.1080/03055698.2020.1740977 